\title{
"Change is Coming": Imagined Futures, Optimism and Pessimism Among Youth Climate Protesters
}

\author{
Jasper Cattell
}

\begin{abstract}
In recent years, two unrelated developments have opened up new opportunities for examining how young people relate to climate change and participate in climate politics. First, there is a fast-growing literature in sociology and youth studies concerned with the roles of imagined futures in social action. Second, and more recent, is an explosion of youth-based climate activism, particularly the Fridays For Future movement. In this paper, I draw from in-depth interviews with participants in the Fridays For Future protests in London in Spring 2019, arguing that in this case of youth mobilization, protesters relied on shared, overarching narratives about the future of climate change, albeit ones that allow room for some divergence in opinion. In particular, I examine how regular involvement in the movement influenced participants' imagined futures. Drawing from studies of similar issues by Kleres and Wettergren (2017) and Threadgold (2012), and from the phenomenological concept of "orientation" (Ahmed, 2005; Carabelli and Lyon, 2016), I argue that regular and repeated participation in climate activism engenders optimism among youth. This opens new ways of thinking about the relationship between political action and young people's anticipations of climate change, with implications for scholarship of imagined futures, youth politics and climate politics.
\end{abstract}

Keywords: Imagined Futures, Fridays For Future, Optimism, Pessimism, Climate Activism

Jasper Cattell was most recently a Master's student at the London School of Economics and Political Science, where he received an MSc in Political Sociology. His current research interests include youth politics, future studies and contemporary social movements, and he has previously published on right-wing populism. He can be contacted at jasper.m.cattell@gmail.com. 
Cattell

\section{Introduction}

"You've run out of excuses and we're running out of time. We've come here to let you know that change is coming whether you like it or not" (Thunberg, 2019, p. 16).

These words, spoken by then 15-year-old climate activist Greta Thunberg at the 2018 COP24 conference, are more than an indictment of past actions. They also express a prediction about the future: one of climatic catastrophe, fast approaching and ignored. Thunberg began striking from school and protesting outside the Swedish Parliament in November 2018 to demand that more serious action be taken on climate change. Since then, an international movement called Fridays For Future has grown, as high school and university students have left their classes and taken to the streets - thousands across the globe weekly, with coordinated global strikes attracting millions of demonstrators. While there are region-specific goals, the overarching demand is the same: act on the future. Time is running out.

In recent years, a growing number of sociologists have pointed out an underexplored area of inquiry: much like the politicians Thunberg confronted, we have tended to downplay the future in sociological analysis. As a result, there is a growing literature focusing on the ways in which actors think about what is ahead and how it influences their actions in the present. This is particular salient in youth studies, where scholars have been examining the ways in which young people imagine and plan for their futures at critical junctures (Carabelli \& Lyon, 2016). The future is unknowable, and we are generally bad at accurately predicting it, but action generally entails consideration of both the outcomes of our actions and the state of the world in the future, making imaginations of the future central to issues of action, agency and identity (Frye, 2012; Mische, 2009; Schütz, 1967).

This paper builds on literature in youth studies, social movement studies, and the sociology of the future. Using the extended case method, I draw from in-depth interviews I conducted with ten young people who participated in the Fridays For Future climate strikes in 2019 to examine how they imagined the future of climate change and how this played into their political activism. I argue that in this case of youth mobilization, protesters relied on shared, overarching narratives about the future of climate change, but that these narratives allowed room for divergence and disagreement. In particular, I demonstrate that participants' orientations towards the future appear to diverge over time based on their level of involvement, arguing that among these youth protesters, repeated involvement in climate activism fosters a greater sense of optimism about the future of climate change. In the conclusion, I briefly discuss how this can be explored further, along with the more general potential of the youth climate movement for research into imagined futures and youth activism. First, however, I need to discuss what it means to study imagined futures.

\section{Imagining the Future}

“The future,” writes Mark Fisher (2012, p. 16), “is always experienced as a haunting: as a 
virtuality that already impinges on the present." The expectations that agents have about the future have a double relationship to action: imagined futures influence action by providing goals, blueprints and general directions for agents, while agents also shape and reshape their imagined futures in the "the very act of moving toward the future" (Carabelli \& Lyon, 2016, p. 1111). Despite this, imagined futures were relatively underdiscussed of sociology for several decades, leading to what Michèle Lamont has called a "black-boxing" of the future in theories of social action (Lamont \& Hylm, 2019, 178). In the past decade, some scholars have moved to address this gap by focusing on imagined futures as their own object of analysis. The resulting literature includes theoretical accounts of how imagined futures are developed and how they influence actions (Mische, 2009; Tavory \& Eliasoph, 2013; Tutton, 2017), along with empirical studies, such as Margaret Frye's (2012) study of how Malawian schoolgirls use educational aspirations to define their identities.

By imagined futures, I am referring to subjective ideas about what will happen in the future and how we can influence it. They are "in our heads" (Mische, 2014, p. 438), but are deeply influenced by cultural and material contexts, subject to influence from others and a core part of how we orient our actions in the world around us. They are often taken for granted, but not always (Tavory \& Eliasoph, 2014; Tutton, 2017). Beyond this, the sorts of futures one studies will vary depending on one's case and research goals. One may want to focus more on the short-term than the long-term, or about agents' imaginations of individual life-courses over their imaginations of the future of their broader social context. The interviews I conducted touched on all of these different areas of future imagining, but the main focus of this study are macro-social futures rather than individual ones.

Images of the macro-social future, which include expectations about the state of the economic, political and social spheres, are important in politics. Collective anticipation is key in areas like "coalition formation, political mobilization, institution building, and policy reform" (Mische, 2014, pp. 457-458), since common ideas about the future provide the basis for coordinated action. This can be seen in a variety of political scholarship, including Fisher's writing on "capitalist realism" (2009, p. 4), Mische's (2014) study of environmental political actors, theorizations of threat in social movement formation (McAdam \& Boudet, 2012) and discussions of the notion of historical progress in politics (Arendt, 1963; Benjamin, 1968). Imagined futures are particularly important in environmental politics, because the most severe effects of climate change will occur in the future, so preventing them requires political action in the present (Giddens, 2011). As a result, anticipations of the future have featured prominently in environmentalist discourse (White, 2017) and particularly in the recent explosion of youth climate activism, including the aptly named Fridays For Future movement. For this reason, Fridays For Future provides new opportunities for examining how young people think about the future of climate change, and how they respond to these imagined futures politically.

This paper only begins to explore this potential, pointing to some preliminary conclusions about the movement and its participants. Bringing the theoretical accounts mentioned above and the results of in-depth interviews with youth protesters in conversation with literature from social movement theory, phenomenological sociology and youth studies, I argue that participants in the movement relied on shared narratives about the future, but that each individual's relative optimism or pessimism diverged based on how regularly they participated in climate action. 


\section{Methodology}

This paper is based on a small-scale study conducted in 2019, composed of in-depth, semistructured interviews with ten participants in the Fridays For Future demonstrations in London. With such a small sample, its results are not generalizable to the entire movement, or to youth climate activists in general, but that is not the goal of the study. Rather, following Mario Luis Small's (2009) articulation of the extended case method, the goal is to generate hypotheses from a small sample. I used a sequential sampling method, choosing participants and refining interview scripts "based on increasingly refined and continuously re-evaluated understanding of the underlying phenomenon," until "each new interview is telling [me] very little [I] had not already heard about the" phenomena of interest (Small, 2009, p. 26). Through this approach, I developed "logically sensible hypotheses" (Small, 2009, p. 28) about the role of imagined futures at the micro-level of the contemporary youth climate movement.

All participants were university students who attended protests in the first half of 2019; for the most part, they attended protests prior to the UK government's declaration of a state of emergency on climate change on May 1. Interviews took place after this event, which was commonly interpreted by participants as a success for Fridays For Future and Extinction Rebellion. Participants fell into three categories: (a) those who were regularly involved in the movement, regularly attending or organizing small-scale weekly strikes in addition to the largescale monthly ones; (b) those who attended one or two large-scale protests and had significant past or present involvement in environmental activism; and (c) those who attended one or two largescale protests but had little past or present involvement in environmental activism and did not identify as activists. (See Appendix A for a list of participants, with some relevant information about their background in environmentalism and activism. All participants have been anonymized and their names have been replaced by pseudonyms.)

There are variety of methodological challenges in accessing imagined futures. According to Mische (2009, p. 702), imagined futures are externalized through speech and writing as images or narratives which can be interpreted hermeneutically as "texts." But they are neither unitary nor static. In conversation, my interviewees did not describe easily pre-assembled images of the future, but flitted between various, often contradictory, possibilities of what the future might be like. We do not, as Alfred Schütz (1967, p. 68) observed, hold a single potential future in our heads at a time; rather, we "orient [ourselves] to multiple futures at once" (Tavory \& Eliasoph, 2013, p. 909).

For this reason, I centred my interviews around an exercise, inspired by Robert Textor's (1989) future-oriented interview methods. I asked participants to construct best-case, worst-case and most likely scenarios for the future of climate change, its effects on society and its effects on them as individuals. The interview context became, in Mische's (2014) terms, a "site of hyperprojectivity" where participants, removed from their daily lives "[locate] problems, visualize alternative pathways, and consider their consequences and desirability" (p. 447). By comparing the results of these interviews, one can find "numerous cognitive and evaluative positions that tend to be held in common" (Textor, 1989, p. 24) about the future. Each interview was coded, first abductively and then with Mische's (2014) method, looking for certain grammatical and narrative structures which indicate imagined futures. (See Appendix B for a list of codes and examples.) 


\section{Agreement and Disagreement on the Future of Climate Change}

The results are structured around a close comparison between the narratives of the future presented in each interview. Similarities were most pronounced in the participants' worst-case scenarios. They offered detailed descriptions of worst-case scenarios, often listing numerous catastrophic consequences. Most participants first listed natural disasters and climatic problems before focusing on their social effects and effects on non-humans. For example, Georgina, a Green Party activist said,

I don't think people will go extinct very quickly, I wouldn't go that far. But I would say countries being flooded, some countries, which is already happening of course in Bangladesh. And other parts of the world becoming way too dry. Massive climate migration, which obviously brings problems with it. Where do people go? How do they go to the places? I mean, the fact that the refugee crisis in Europe was already such a big deal, and that was for fleeing war, and that already people were like "Euhhh go away," imagine what would happen to people fleeing climate change, you know? [...] Animals going extinct, species going extinct, plants going extinct, plant species.

Others were more drastic in their scenarios. For example, Sarah, a former student organizer described the worst-case scenario as

all the pacific islands; island nations disappearing. Coastal cities disappearing [...] wars and refugee crisis will displace people. I do believe that society will break down and things won't work anymore. We won't be able to have international arrangements and governments and companies and shit because things will be so chaotic. So, I'm sure things will go very totalitarian too, because governments will get protective and just close their border and horde their resources and stuff like that.

Most of these worst-case scenarios had, in Mische's $(2009,2014)$ terms, high degrees of clarity and low degrees of contingency, meaning participants see them as likely to happen if no intervention is taken. This was confirmed in a follow-up question, which asked how we reach the worst-case scenario. Blake, a weekly climate striker summed up the general sentiment when he said, "[W]e get to [the worst-case] future by status quo politics, we get to that future by emphasis on individual action." Albert, another former Green Party organizer, said that a worst-case scenario was "neoliberal climate change."

Next, I asked about their best-case scenarios. These were more varied, both in their content and in their degree of clarity; I focus more on these differences later. As for similarities, partici-

\footnotetext{
${ }^{1}$ Only Bella disagreed with this sentiment, saying, "we will have to be worse than we are today" to achieve the worst-case scenario.
} 
pants all focused on three general areas of improvement in the short- to medium-term: more stringent international agreements; increased regulation on travel, meat and other high-polluting industries; and changes in culture and consumer habits. Many, such as Albert, stressed "more local living." Major differences, discussed below, arose on whether such measures would be enough without more systemic changes.

When I asked about their most realistic scenario, participants highlighted how some action would prevent their worst-case scenarios from happening, but that it would not be enough to counteract the damage done. Bella, one of the organizers of the weekly London strikes, and one of the most optimistic participants in her overall outlook, said,

I do think that a lot of non-human species are going to go extinct, and they already are. I do think we are going to decrease the resilience of our whole planet and most ecosystems quite severely. [...] But I do think that we are going to stop emissions eventually. It might not be in ten years, but I do think it is going to happen. It is already becoming more and more, like, in people's minds. I think people are going to change their habits slightly [...] and countries are going to use other types of energy sources. And I'm sure that the Paris Agreement will continue to increase its ambition.

Evident in Bella's response is an expectation every participant stressed: the irreversibility of climate change even if full carbon neutrality is achieved in the near future. As a result, even the most optimistic best-case scenarios revolved around adapting to damage that either has already occurred or is inevitable. "I personally would way prefer mitigation, but I think we'll have to do some adaption," said Camille, an environmental policy student and a first-time climate protestor, when answering the best-case question. ${ }^{2}$ The general sentiment, as Georgina put it, was that "even if we do something about [climate change], it will still always be a threat, and we can never just think like, 'Okay, we've fixed the climate, and now we can just move on." Sarah described the effects of climate change as not having a "peak," as this would imply a reversal, but leading to a "plateau where it's just going to be horrible. And after that it'll just stay horrible."

Frequently appearing in these statements is what Mische (2014, pp. 454-55) calls the "predictive mode": assertions of "likelihood that something will happen in the future." This contrasts to most participants' best-case scenarios, which relied on the "imperative mode" and "subjunctive modes" (p. 454), focusing on calls to action and emotional orientation, respectively. The reliance on the predictive mode in these statements indicates a greater certainty in some narratives over others; in this case, participants were universally certain of the irreversibility of climate change, even in the long term.

Two interrelated terms that came up in every interview without my prompting were privilege and responsibility. Participants used the former to stress how geographical differences

\footnotetext{
${ }^{2}$ Camille is referring to a common differentiation between mitigation - reducing and stabilizing emissions - and adaption - responding to changes that are already present or inevitable.
} 
and global inequalities conspire so that climate change is a more serious and urgent threat for people in certain parts of the world. The general message was that "climate change is [...] not something that's going to happen, it's happening right now [...] to other people," as Elsa put it. "To other people it's a threat in terms of their entire lives and livelihoods being swept away." But participants did not feel personally threatened, although did expect to feel both physical and emotional discomforts as a result of climate change. All expected to experience limited environmental consequences; many predicted heatwaves, likely because one was occurring when I conducted many of the interviews. They also expected indirect consequences; "political and social strife" (Anna), decline in easily accessible nature or natural resources, food shortages, crises from refugee influxes and general malaise were all mentioned. One consequence, said Sarah, is "just feeling sad for everything else."

The term responsibility was invariably invoked in such discussions; for example, Bella stressed a sense of solidarity towards people experiencing more drastic consequences of climate change, mentioning "solidarity mechanisms" to "help populations that live very close to the sea" when disasters related to sea-level rises occur. Elsa discussed a sense of "responsibility to the natural environment" and to those most affected because of her personal contribution, not because of a perceived need to "fight for people who can't fight for themselves." When discussing both privilege and responsibility, participants seemed to be navigating a disjunction between their individual futures and those of the planet, previously observed by Steven Threadgold (2012) among individuals of approximately the same age cohort as my participants.

These accounts show several themes about the future that were held by all participants: that climate change is irreversible, that its effects vary by geography and privilege, that the path forward is more about adaption than mitigation, and that we have a responsibility to those who will be the most affected. While participants regularly talked about potential objections to their positions on other subjects, these points were presented as simple fact. It is not surprising that such similarities appeared, since a key part of political mobilization is the convergence of collective meanings concerning problems, solutions, the identity of the collective actor and, importantly, temporality (Melucci, 1996, p. 55, pp. 77-80).

Social movement scholars tend to emphasize the interaction between internal processes of meaning making and cultural "codes," "contexts" and "institutions" (Swidler, 1995, p. 25; see also Snow and Benford 1988) when determining the origins of collective meanings. However, it is important to note two additional potential sources of participants' shared imagined futures. First, Jacqueline Kennelly (2009) highlights the ways in which student activist spaces can privilege a certain habitus, creating pressure for conforming narratives in such spaces. And second, Tad Skotnicki (2019) argues that collective meanings are, in part, dependent on the phenomenological character of the problem a social movement is attempting to address. This explanation fits this case particularly well, as it at least partially roots similar imagined futures in shared experiences of the temporality and geography of climate change, as a problem which is more destructive in the future and unequal in its effects.

That being said, common meanings are never fully fixed and social movements "are not 'subjects' that act with [...] unity of purpose" (Melucci, 1996, p. 78); "agreement on one dimension" of collective meaning "does not ensure unanimity with respect to other dimensions" (Snow and Benford, 1988, p. 204). Certain concepts, such as climate change and capitalism func- 
tion as "floating signifiers:" terms which "partially fix meaning" but can be subject to a variety of interpretations, allowing the construction of solidarity between subjects with contradictory ideas within the same discursive field (Laclau \& Mouffe, 2014, pp. 99-100). As a result, participants often disagreed on the specifics of what initially appeared to be shared narrative.

The main subject of disagreement concerned reforms to existing institutions, and to the capitalist world-system more broadly, and whether they would be sufficient to avoid climatic disaster. All participants acknowledged that capitalist economic practices play a decisive role in climate change. But opinions varied between those who focused on reforming capitalist institutions as the most strategic short-term approach, and those who focused on how this is pointless in the long-term. For several participants, facing the challenge of climate change would require major changes in how capitalism works, if not its downfall. "This whole capitalist mindset and society. That would have to go, or at least in some part has to change," said Georgina. Sarah described the United States as "too deeply embedded in being capitalist" to make major policy changes to address climate change, while Edward, Albert and Blake all drew links between capitalism, the tendency to rely on individual-level solutions and a lack of sufficient action on climate change. These participants held similar views on other institutions. For example, Anna, describing her bestcase scenario, said it was impossible for "work within the system solutions" to be effective. Later, when asked if she had hope, she said, "I think that the current [political] climate is unsustainable. I hope it will collapse and I think it will as well."

In contrast, Camille's, Walter's and Bella's accounts were less contingent on the fall of capitalism, often stressing the need to address climate change within reformed versions of current institutions. All three stressed the strategic dimension of this approach. For example, when asked about anti-capitalism Bella said:

That is my personal belief as well. I think the most simple way of dealing with climate change would be to get rid of capitalism. However, I think there might be other solutions. So, I don't think that's necessarily the only solution. That would be a doomed game of trying to convince people to be left and to care about climate change at the same time. [...] Get more people on board and they can create more solutions to the problem.

Such differences of opinion were never enough to threaten the shared, overarching vision of the future help by all participants, which stressed irreversibility, privilege, mitigation and responsibility. They appeared around the ambiguities of key concepts in the participants' shared narratives, but the overarching vision and goals were the same. For those who thought that reform and regulation were suitable paths forward, they were to be taken to adapt to an irreversibly changing climate and to fulfil the responsibilities we have towards those most affected. Similar motivation can be found among those who discussed the need for revolutionary change. This indicates two conclusions about the role of imagined futures in my participants' activism: first, that participants' shared ideas about the future play a structural role in the social movement, as discursive "nodal points" (Laclau \& Mouffe, 2014, p. 99) which facilitated mobilization around a 
shared vision about the future; and second, these common meanings were general enough to subsume the differences that emerged in individual- and subgroup-level narratives. ${ }^{3}$

\section{Variations in Optimism and Pessimism}

So far, I have discussed the main areas in which participants agreed and disagreed about the future. This, however, is based on static observations, taken during interviews. It gives no clue to how participants' imagined futures might change over time. But divergences emerge when by employing two levels of comparison. By first comparing the content, length and depth of each participants' three scenarios, along with their answers to other questions, a picture emerges of each participants' general orientation towards the future of climate change. Then, by comparing participants against each other, a pattern emerges: despite sharing some key overarching ideas about the challenges posed by climate change and the general path to addressing them, those more regularly involved in climate action tended to be more optimistic than others about whether we actually will address these challenges in practice.

First, however, I should qualify my uses of optimism and pessimism. Following literature on the role of emotions in social movements, I use them to describe "long-lasting affects" with no specific object: one a generally hopeful orientation - in the phenomenological sense of the term ${ }^{4}$ - towards the future and the other a discouraged or potentially fearful one (Goodwin et al., 2001, pp. 10-11). They describe certain moods or outlooks found in narratives, not essential characteristics of a person. Of course, no participant was entirely optimistic or pessimistic. When asked directly, even those who were in favour of more systemic or revolutionary change thought that the protests were at least somewhat effective at changing current policy. Similarly, when asked, nearly everyone said they had some hope. Furthermore, such orientations are not entirely 'emotional' (as opposed to 'rational'), as they are, in part, rationally extrapolated from past events and knowledge of the phenomenon. ${ }^{5}$

But while all participants drew on optimistic and pessimistic ideas about the future, each individual tended to lean more on one than the other. This can be seen in the relationship between each participants' three scenarios. Some participants' worst-case scenarios were more elaborate than their best-case scenarios, with a higher degree of clarity, use of the predictive mode and more sombre tones of voice. These participants' most realistic scenarios leaned more towards their worst-case scenarios. They rejected the accuracy of apocalyptic narratives of climate change when I asked directly but tended to use apocalyptic images throughout the conversation, often with a

\footnotetext{
${ }^{3}$ For a more in-depth discussion of agreement, disagreement and environmental protest, see Kakenmaster (2019).

${ }^{4}$ The term orientation - applied to the study of youth futurity by Carabelli \& Lyon (2016) - implies a repeated, habituated focus on certain objects over others. In the context of future studies, it can refer to imagined futures which an actor is more focused on than others, and thus become the futures which they try to achieve, prevent or alter through their actions, while in turn putting other potential futures figuratively "behind" them (Ahmed, 2005, p. $538)$.

${ }^{5}$ For example, when I asked about the next steps for the movement, those who employed more pessimistic themes generally suggested that the movement undertake more disruptive action, while those who were more optimistic about the effects of the current movement focused more on building on current strengths. Both of these are rational responses, given their background assumptions.
} 
darkly humorous slant. As Edward said, "Rapture is an event that promises a certain kind of freedom - we will all go extinct together. Quite nice, it takes away a total fear of loneliness. [...] Try not to be Rapture-like, because I think the Rapture is too positive."

For another group, it was more balanced: best-case scenarios tended to be as elaborate as their worst-case, with similar length, clarity and non-verbal communication. These participants' most realistic scenarios fell closer to their best-case scenarios and drew on more optimistic themes, relative to the other participants. Those who employed more optimistic themes were generally more involved in the movement or involved in regular and serious discussions about the future of climate change. This includes Bella, Blake and Walter, who attended protests on a weekly basis, who all referenced the joy and hope they get from the protests as a reason for their regular attendance. Camille, who, like Bella and Walter, studied environmental policy, also presented exceptionally optimistic narratives. Conversely, those who were one- or two-time protesters and were not presently involved in an ongoing action or discussion about climate change tended towards pessimistic themes, even those who had been formerly involved in climate action. Several mentioned how they had been optimistic while involved in action in the past but felt far more pessimistic now. Every participant said that attending the protests made them feel more hopeful.

Walter Benjamin (1978, p. 55), drawing from Pierre Naville, argues that pessimism towards one's social context can provide an impetus for solidarity and struggle through a shared "mistrust in all reconciliation" in the future. While Benjamin may overstate pessimism's importance, he reminds us that at least some shared pessimism might initially be useful for motivating mobilization, provided it is not so overwhelming that it makes acting seem meaningless. All participants stressed how there is no going back, foreclosing some optimistic options but not so many that there is no reason to act. Even those who employed more optimistic themes narratives about reform within capitalism still recognized capitalism's barriers to effective climate action and a need to change it.

But despite some shared pessimism, there is also a clear pattern of divergence, as those more involved over time drew more from optimistic themes in their interviews. In a previous study of youth climate protesters, Jochen Kleres and Åsa Wettergren (2017, p. 508) argue that environmental movements provide space for "emotion management." They found that climate activists experience fear, which is managed through other emotions - hope, anger and guilt shaping the cognitive lens through which they act and make strategic choices, both as individuals and as a collective. Emotional orientations are not just "intimately involved in the processes by which people come to join social movements;" they are also part of their "ongoing activities" (Goodwin, et al., 2001, p. 18) and participation can reinforce emotions and "elaborate intuitive visions" (p. 19). My results support and expand Kleres and Wettergren's argument, since my participants ranged in levels of involvement from attending one or two protests a year to protesting weekly. It makes sense that more involved participants experience more "emotion management" and thus become more optimistic. Similarly, some of those who were not regularly involved in the Fridays For Future protests, but were involved in other regular, productive actions concerning climate change for school or work, were similarly optimistic. Optimistic orientations appeared among these participants as strongly as it did among dedicated activists, indicating the importance that emotion management external to the social movement can have. 
This hypothesis - that youth who are more involved in regular climate change action are more optimistic about the future of climate change - requires further testing, since it relies on static observations using interview methods. Thus, it is worthwhile considering a potential counterinterpretation of the results that reverses the causal relationship hypothesized here: that more optimistic young people are drawn to more regular involvement in social movements. In this interpretation, optimism and pessimism are too deeply rooted in either individuals' political habitus or psychological profile to change in either a social movement or another form of regular, engaged climate action.

There are two reasons why this interpretation is implausible. First, my participants came from a variety of backgrounds, in terms of class, nationality, gender and educational profile, indicating that, if further examined, there would likely be differences in their habitus (Bourdieu, 1990). These demographic characteristics do not correlate to levels of optimism or pessimism. And even if they did, past work on youth activism and agency emphasizes the ability of habitus and political subjectivity to shift in new contexts (Coffey \& Farrugia, 2016), and particularly in youth activist spaces (Kennelly, 2009). Second, almost all of the participants who were not regularly involved in the protests in 2019 had been regularly involved in environmental activism in the years prior to the study. Most of them said that they felt more optimistic when they had been partaking in climate activism regularly. A deep-rooted, optimistic psychological profile that drew young people to action could not explain why participants were optimistic enough to act previously, why they seemed more pessimistic when interviewed and why this change occurred.

The argument presented here is also consistent with a core insight from phenomenology: individual's orientations are developed through repeated actions (Ahmed, 2005). The repeated act of protesting involves approaching the issue of climate change in a different way than occasional protest. All of my participants thought of climate change in the long-term, drawing from familiar themes like "future generations" (White, 2017, p. 763) and apocalyptic imagery, providing their narratives with both a repeated unit of time and a cataclysmic rupture of this repetition. But those attending protests regularly discussed the short-term in more detail. Bella and Blake in particular talked about how their actions made them focus on smaller strategic goals and the day-to-day work of organizing or participating. I suspect that this underlies the broader pattern of optimism and pessimism: the repeated act of acting towards on the future of climate change altered what those more regularly involved focused on, orienting them more towards immediate goals and less towards long-term narratives of climate catastrophe. Thus, while they held similar long-term narratives to others, these narratives did not dominate our interviews to the same extent as they did in my interviews with less regularly involved participants.

This explains why regularly active participants had similarly catastrophic worst-case scenarios as their less active peers, while also being more optimistic in their best-case and most likely scenarios. It would also explain the variation between my study and Threadgold's (2012), who found similarly catastrophic narratives about the future of climate change among Australian high school students as I did among my participants. He demonstrates how his participants learned to prioritize their individual futures and bracket the macro-level threat of climate change through practices of governmentality in their schools, leading him to "pessimistic [...] conclusions" (Threadgold, 2012, p. 2) about their capacity for environmental politics. I found very different political outcomes, even among my most pessimistic participants, despite the overlap in imagined 
futures between my study and his. The key difference, I would contend, is not in their ability to imagine pessimistic or catastrophic futures of climate change, but rather their practices, and how those practices focus them towards certain futures over others.

It is tempting to say that if youth feel optimistic about our chances to prevent climatic disaster, they will be encouraged to act politically. I do not mean to discount optimism as a motivator for action, but we should not discount pessimism either. As Benjamin reminds us, there can be a motivational force to pessimistic feelings - from being "apocalypticians only in order to be wrong" (Günther Anders, quoted in Latour, 2017, p. 217), as Thunberg (2019, p. 45) is when she says "the house is on fire." Nor should we forget that our ideas about the future, including the extent to which we lean towards optimism or pessimism, can change as we act. The results of my study, along with the conclusions of Kleres and Wettergren's, indicate that in youth climate activism, activism engenders optimism, making it as least as much an outcome of climate activism as it is a cause.

\section{Conclusion}

I have made three main claims about the ways in which young participants in the Fridays For Future protests imagine the future, and how this plays into their activism. First, protesters relied on a shared narrative about the future of climate change, which posits that climate change is irreversible, but that mitigation strategies are still possible and that those possessing geographical and economic privilege have a responsibility to pursue them. Second, this common narrative leaves room for disagreement, particularly around the interpretation of issues like the feasibility of reforms, as opposed to revolutionary change. Third, individuals diverged in their general optimism or pessimism about the future of climate change depending on their level of involvement in climate action.

There are several potential avenues for further research. The first two conclusions can help us understand the current youth climate movement and the roles that imagined futures play, while following existing literature on agreement and disagreement within political blocs. ${ }^{6}$ They could be further examined through survey methods, which could provide a clearer picture of shared narratives across a subset of the youth climate movement. The relationship postulated in the third conclusion could be explored using a longitudinal study or ethnographic methods to examine how participants' futures shift over time, particularly looking at the relationship between regular involvement and optimism. ${ }^{7}$

This relationship has implications for policy makers, educators, activists and others who are concerned that climate change can be so overwhelming that it might inhibit action. If further substantiated, it indicates that active participation in regular practices focused on combating climate change reorients agents and engenders optimism, perhaps helping combat climate-related despair and anxiety. There are also implications concerning the ways different social contexts provide spaces for practices which engender optimism, as seen in the variation between my study

\footnotetext{
${ }^{6}$ See Laclau and Mouffe (2014) and Melucci (1996) for discussions of this subject generally, and Kakenmaster (2019) for a more focused discussion of these topics in climate activism.

${ }^{7}$ Ethnography was considered for this study but was abandoned because of ethical issues of conducting covert participant observation when school strikers under eighteen years of age were present.
} 
and Threadgold's. Given the current interest in imagined futures in sociology and youth studies, and the meteoric rise of youth climate activism, such issues are now more relevant than ever, academically and politically. Since youth have a central role in struggles over climate change, not just as 'future generations' but as actors themselves, their imagined futures are important to understanding contemporary climate politics. The findings here are only preliminary but indicate some of the many possible direction we can take in the study imagined futures in youth climate activism.

\section{Acknowledgements}

Thank you to Michael McQuarrie and Liene Ozolina for providing me with advice as I designed this project; to Jonathan White for an invaluable semester of seminars on future studies; to Chris Van Kalkeren, Joanna Zhao and Susan Fitzgerald for providing feedback on my drafts; and to my fellow climate strikers, particularly those who let me interview them, for their comradery, companionship and commitment to finding a way through whatever lies ahead.

Appendix A: Participants

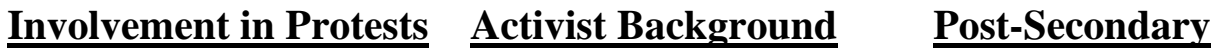

$\begin{array}{llll}\text { Albert } & \text { Attended 1 } & \text { Green Party organizer } & \text { Philosophy, sociology } \\ \text { Anna } & \text { Attended 1 } & \text { None } & \text { Social policy } \\ \text { Bella } & \text { Attended weekly } & \text { Environmental activist } & \text { Environmental policy } \\ \text { Blake } & \text { Attended weekly } & \text { None } & \text { Social policy } \\ \text { Camille } & \text { Attended 1 } & \text { None } & \text { Environmental policy } \\ \text { Edward } & \text { Attended 1 } & \text { Social justice activist } & \text { Philosophy } \\ \text { Elsa } & \text { Attended 2 } & \text { None } & \text { Geography, sociology } \\ \text { Georgina } & \text { Attended 1 } & \text { Green Party organizer } & \text { Sociology } \\ \text { Sarah } & \text { Attended 1 } & \text { Environmental activist } & \text { Environmental science } \\ \text { Walter } & \text { Attended weekly } & \text { Unknown } & \text { Environmental policy }\end{array}$




\section{Appendix B: Coding Examples}

This is not an exhaustive list of the codes used but highlights the ones I used most in the analysis above.

Code

Apocalyptic

Anti-

Apocalyptic

Catastrophism

Clarity

Collective

Responsibility

Connectivity

Contingency

\section{Definition}

Narrative or imagery that is apocalyptic; describes, for example, end of human life on Earth.

Actively pushing back against apocalyptic imagery or narratives.

Narrative or imagery which postulates catastrophic consequences of climate change but stops short of apocalypse.

"Degree of elaboration or detail" about the future (Mische, 2014, p. 444).

An expression of a shared responsibility, often for the causes of climate change, to the planet or to the most affected.

"Imagined logic of temporal connection" (Mische, 2014, p. 444).

"Pre-fixed vs. flexible, uncertain, dependent futures" (Mische, 2014, p. 444).

\section{Example}

"I try not to be a pessimist, but definitely, lately I've been like 'We're all gonna burn, we're all gonna die."'

"I think the worst-case scenario will be ... I don't think people will go extinct very quickly, I wouldn't go that far."

"Pacific islands; island nations disappearing. Coastal cities disappearing. Like I said before, wars and refugee crisis will displace people."

High clarity: "We're going to like advance green technology a lot. Probably be some carbon capture systems. Um, because I think that especially for an American ideology, if we think about fighting climate change as a way to grow. So, like creating green technologies and creating companies and stuff, they'll be motivated to do that."

Low clarity: "very few species, very few, like - very little life on the planet and a very unpredictable climate and harsh environment."

"It's more realizing that I have contributed and what practical steps can I take or how can I show support for the change I want to see happen, how can I get involved."

"We get to that future by status quo politics, we get to that future by emphasis on individual action."

High contingency: "So it really depends on the political situation [in the US]." 


\begin{tabular}{|c|c|c|}
\hline & & $\begin{array}{l}\text { Low contingency: "even if we do something about [climate change] } \\
\text { it will still always be a threat." }\end{array}$ \\
\hline Optimism & Reference to hope in the future. & $\begin{array}{l}\text { "So, I don't think we're responding to it very well, but I'm still } \\
\text { hopeful that we can." }\end{array}$ \\
\hline $\begin{array}{l}\text { Imperative } \\
\text { Form }\end{array}$ & $\begin{array}{l}\text { "A call to action of some sort so as to bring a } \\
\text { future possibility into existence" (Mische, } \\
2014, \text { p. 252). }\end{array}$ & $\begin{array}{l}\text { "We need net zero as soon as possible. I believe if we don't that the } \\
\text { planet will not be liveable within the next eighty years." }\end{array}$ \\
\hline Inequality & $\begin{array}{l}\text { Reference to economic, material or social } \\
\text { inequalities, usually related to the effects of } \\
\text { climate change. }\end{array}$ & $\begin{array}{l}\text { "And of course, the people who - countries that have done the least, } \\
\text { the people who have done the least to cause climate change will } \\
\text { suffer the most and will suffer first." }\end{array}$ \\
\hline Pessimism & $\begin{array}{l}\text { Reference to hopelessness about the capacity } \\
\text { to change the future. }\end{array}$ & $\begin{array}{l}\text { "I think action will be taken, but I'm afraid that it won't be quick } \\
\text { enough." }\end{array}$ \\
\hline Predictive Form & $\begin{array}{l}\text { "A statement of the likelihood that } \\
\text { something will happen in the future, often } \\
\text { associated with an assertion about causality, } \\
\text { conditionality or sequence" (Mische, 2014, } \\
\text { p. 454). }\end{array}$ & $\begin{array}{l}\text { "I don't think realistically it's going to affect me that much in my } \\
\text { lifetime. I think I'm going to watch it in the news and be upset }[\ldots] \\
\text { but I don't think it's going to change my life." }\end{array}$ \\
\hline $\begin{array}{l}\text { Personal } \\
\text { Privilege }\end{array}$ & $\begin{array}{l}\text { Related to inequalities; a reference to one's } \\
\text { own privileged position in a system of } \\
\text { inequalities, usually concerning the effects of } \\
\text { climate change. }\end{array}$ & $\begin{array}{l}\text { "I figure that I don't really face that much of the consequences. I } \\
\text { will probably have a nice life. But I'm more concerned about } \\
\text { people that don't have the means to protect themselves. [...] So } \\
\text { yeah, in the West I think we'll definitely be comfortable." }\end{array}$ \\
\hline $\begin{array}{l}\text { Subjunctive } \\
\text { Form }\end{array}$ & $\begin{array}{l}\text { "An expression of value, emotion, } \\
\text { orientation subjective stance in relation to a } \\
\text { possible, but uncertain, future event." } \\
\text { Mische, } 2014, \text { p. } 454) \text {. }\end{array}$ & $\begin{array}{l}\text { "I don't know, cause it kind of frustrates me. I feel like you have to } \\
\text { be more radical and you have to say like, cause I don't think we're } \\
\text { going to actually fight climate change under capitalism, so I feel } \\
\text { like you have to say that." }\end{array}$ \\
\hline Temporal Node & $\begin{array}{l}\text { Inspired by Laclau and Mouffe's }(2014, \mathrm{p} \text {. } \\
\text { 99) concept of a "nodal point"; refers to } \\
\text { central moments in the past or future around } \\
\text { which imagined futures are structured. }\end{array}$ & $\begin{array}{l}\text { "Well, what we saw with Extinction Rebellion, yes, that was } \\
\text { definitely effective. [...] I think civil disobedience and disruptive } \\
\text { tactics definitely work better [...] And yeah, you see that with } \\
\text { Extinction Rebellion it worked." }\end{array}$ \\
\hline Urgency & $\begin{array}{l}\text { A reference to the urgency of climate } \\
\text { change. }\end{array}$ & "It's urgent because you already see the effects." \\
\hline
\end{tabular}




\section{References}

Ahmed, S. (2006). Orientations: Towards a queer phenomenology. GLQ: A Journal of Lesbian and Gay Studies, 12(4), 543-574.

Arendt, H. (1963). On revolution. Penguin Books.

Benjamin, W. (1968). Theses on the philosophy of history. In H. Arendt (Ed.), Illuminations (pp. 253-264). Schocken Books.

Benjamin, W. (1978). Surrealism: The last snapshot of the European intelligentsia. New Left Review, 108, 47-56.

Bourdieu, P. (1990). The logic of practice (Richard Nice, Trans.). Stanford University Press. (Original work published 1980).

Carabelli, G., \& Lyon, D. (2016). Young people's orientations to the future: Navigating the present and imagining the future. Journal of Youth Studies, 19(8), 1110-1127.

Coffey, J., \& Farrugia, D. (2014). Unpacking the black box: The problem of agency in the sociology of youth." Journal of Youth Studies, 17(4), 461-474.

Fisher, M. (2009). Capitalist realism: Is there no alternative? Zero Books.

Fisher, M. (2012). What is hauntology? Film Quarterly, 66(1), 16-24.

Frye, M. (2012). Bright futures in Malawi's new dawn: Educational aspirations as assertions of identity. American Journal of Sociology, 117(6), 1565-1624.

Giddens, A. (2011). The politics of climate change (2nd ed.). Polity Press.

Goodwin, J., Jasper, J. M., \& Polletta, F. (2001). Introduction: Why emotions matter. In J. Goodwin, J. M. Jasper \& F. Polletta (Eds.), Passionate politics: Emotions and social movements (pp. 1-24). University of Chicago Press.

Kakenmaster, W. (2019). Articulating resistance: Agonism, radical democracy, and climate change activism. Millennium: Journal of International Studies, 47(3), 373-397.

Kennelly, J. J. (2009). Youth cultures, activism and agency: Revisiting feminist debates. Gender and Education, 21(3), 259-272.

Kleres, J., \& Wettergren, A. (2017). Fear, hope, anger, and guilt in climate activism. Social Movement Studies, 16(5), 507-19.

Laclau, E., \& Mouffe, C. (2014). Hegemony and socialist strategy: Towards a radical democratic politics (2nd ed.). Verso Books.

Lamont, M., \& Hylm, A. (2019). The world is not a field - an interview with Michèle Lamont. Sociologisk Forskning, 56(2), 167-79.

Latour, B. (2017). Facing Gaia: Eight lectures on the new climatic regime. Polity Press.

Madden, D. (2019). Editorial: City of emergency. City, 23(3), 281-284.

McAdam, D., \& Boudet, H. (2012). Putting social movements in their place: Explaining opposition to energy projects in the United States, 2000-2005. Cambridge University Press.

Melucci, A. (1996). Challenging codes: Collective action in the information age. Cambridge University Press.

Mische, A. (2009). Projects and possibilities: Researching futures in action. Sociological Forum, 24(3), 694-704. 
Mische, A. (2014). Measuring futures in action: Projective grammars in the Rio+20 debates. Theory and Society, 43(3/4), 437-64.

Small, M. L. (2009). 'How many cases do I need?': On science and the logic of case selection in field-based research. Ethnography, 10(1), 5-38.

Schütz, A. (1967). The phenomenology of the social world. Northwestern University Press.

Skotnicki, T. (2019). Unseen suffering: Slow violence and the phenomenological structure of social problems. Theory and Society, 48(2), 299-323.

Snow, D. A., and Benford, R. D. (1988). Ideology, frame resonance and participant mobilization. International Social Movement Research, 1, 197-218.

Swidler, A. (1995). Cultural power and social movements. In H. Johnston \& B. Klandermans (Eds.), Social Movements and Culture (pp. 25-40). UCL Press.

Tavory, I, and Eliasoph, N. (20130. Coordinating futures: Toward a theory of anticipation. American Journal of Sociology, 118(4), 908-42.

Textor, R. B. (1989). A brief explanation of ethnographic futures research. Anthropology Newsletter, 30(8), 1, 24.

Threadgold, S. (2011). "I reckon my life will be easy, but my kids will be buggered': Ambivalence in young people's positive perceptions of individual futures and their visions of environmental collapse. Journal of Youth Studies, 15(1), 17-32.

Thunberg, G. (2019). No one is too small to make a difference. Penguin Books.

Tutton, R. (2017). Wicked futures: Meaning, matter and the sociology of the future. Sociological Review, 65(3), 478-92.

White, J. (2017). Climate change and the generational timescape. The Sociological Review, 65(4), 763-778. 